\title{
Aesthetic Image of the Animal Epithet in Alice Walker's Short Story "Everyday Use"
}

\author{
Shaimaa Hadi Radhi* \\ Thi-Qar General Directorate of Education, Thi-Qar, Iraq \\ Corresponding Author: Shaimaa Hadi Radhi, E-mail: angel.a537@yahoo.com
}

\section{ARTICLE INFO}

\section{Article history}

Received: July 05, 2017

Accepted: October 02, 2017

Published: October 31, 2017

Volume: 8 Issue: 5

Advance access: October 2017

Conflicts of interest: None

Funding: None

Key words:

Aesthetic Inversion,

Alice Walker,

Everyday Use,

Image of Animal,

Womanism

\begin{abstract}
In her short story Everyday Use, the African American writer Alice Walker labels her female characters Mrs. Johnson, and her two daughters: Maggie, and Dee by associating them with an animal quality. In my present paper I attempt to show the central and pivotal role played by the mechanism of 'Animal Epithet' in order to investigate to what extent does the writer apply the theory of 'Womanism' to her short fiction's protagonist and the other characters. Walker wants the reader to share her investigation journey in order to find a logical answer for the crucial questions raised in the research-paper: Why does Walker portray female characters by comparing them to animals? How does Walker manage to treat this topic aesthetically? What portrait of black woman does she prove? To answer these central questions, Walker is committed to construct her short narrative work on the base of the key elements of inversion, signifying, and quilting-like. Walker, as a womanist and animal activist is defiant and ridiculous of the mainstream agent of humanism represented by white males. She aesthetically inverts the meaning of the negative, dehumanizing image devised and everyday used by the men of ruling class into aesthetic and positive one to represent the identity of black women.
\end{abstract}

\section{INTRODUCTION}

Alice Walker, consciously or unconsciously, insists on describing her female characters as animals. Implicitly or explicitly, she is dressing them an animal epithet by attributing to this or that black woman an animal quality. Walker's intention is to reveal the oppressive, racial and humiliating treatment of the white people practised against the black woman in the American community. In her short narrative discourse, she aesthetically mirrors the negative practices of the white people who regard black woman as a mere mule of work. In other words, she rejects such passive everyday uses of 'muleness', which is racially attributed to her black womanish circles.

Goal of the paper, therefore, is to find an answer for each of the following crucial questions:

1-Why does Walker compare her female characters to animals, and not to plants or other things?

2-How does Walker manage to treat this topic aesthetically? 3-What portrait of black woman does she prove?

These questions will be answered in terms of Walker's eco-perspectives and theory of 'Womanism'. In this theory, she adeptly articulates different modes of oppression exerted against women. 'Womanism' is derived from "womanish" which is a term taken from the Southern mothers' folk expression to describe their daughters' behaviour (Collins,
1996, p.10). 'Womanish' refers to courageous, audacious, willful, grown-up, responsible, and serious doings (Walker,1983, p.xi). It is used by Walker as a reaction, opposition, and inversion to the everyday used term which is "girlish, i.e., frivolous, irresponsible, not serious" behavior on the part of black women (1983, p.xi).

She tries to invert whatever bad trait has been adhered to the black women by translating her theoretical views into her short fiction. She makes her female characters "invert the dialectics of master and slave and learn to manipulate signs and deceive the oppressors...., [They] reach the ability to convert pain to art, to estimate their history and to blend it with the archetypal experience of humanity"(Castro-Borrego, 2011, p.37).

Walker sees "black women [as] the most fascinating creations in the world" $(1983$, p.251). Her guide is "heritage, love of beauty, [art] and respect for strength"(Walker, 1983, p.241). She tells her grandmothers' stories to resurrect their art, creativity, aesthetic spirit and humanist nature. Lauret argues that the black woman "values culture that history has given her: Loves music. Loves dance.... Loves the spirit... Loves the folk..." (2011, p.20). In Walker's opinion, black women have a level of genius contrary to the false picture that white culture creates about them as animals and more a kin to working animals like cows, horses, [mules] than other 
human beings (Day, 1972, p.35). Reacting to that, she adopts Virginia Wolf's statement: "genius must have existed among slaves and the wives and daughters of sharecroppers" (Walker, 1983, p.239). Towards her female characters, Walker is so empathetic. She tries to liberate them from the everyday tyranny they encounter by being classified as the" mule[s] of the world" (Christian, 1994, p.44). Working on improving the social conditions of black women would be useful for all black people (Hooks, 1982, p.2).

Philips sees that a characteristic or fact about 'Womanism' is communitarian since:

Womanisim views commonweal as the goal of social change.

Commonweal is the state of collective well-being ...black women's version then extends to encompass all humans, but it does not stop there. Included in this conception of community is what Taliba Sikudhani Olugbala has called "living kind" (alliving things- from humans to animals to plants, to microorganisms,...).(2006, pp.xxv- xxvi)

This fact about 'Womanism' can be seen as an eco-perspective. It refers to unity of the humankind to all living creatures in this universe. For Walker, "this world view essentially emphasizes the oneness of the universe: animate or inanimate"(Bloom, 2008, p.82). Walker, in her essay "Am I Blue" refers to this oneness with animals in particular. She asserts that "everything you do to us will happen to you; we are your teachers as you ours. We are one lesson"(Bloom, 2009, p. 202). In an interview with Bring, she manifests her belief in connection between humans and animals. She really "feel[s] that amazing connection"(1988, p.75). In fact, such connection is an African American tradition. Walker appreciates that "community with animals [can survive] under [different] unfavourable conditions" (Smith, 2012, p. 146). In much of her literary work, she celebrates the association of black women with images of animals. Defending her strong ideas in that respect, Walker's response to some people who criticized her equating or associating humans with animals is that:

"I was [not] equating human beings with animals in a negative way. I mean I definitely do equate them, but positively. It seemed to me so right because the oppression that black people suffer in South Africa- and people of color, women,... is the same oppression that animals endure every day to a greater degree" (Bring,1988, p.70).

Walker's Everyday Use has received a great deal of discussion and study, however there is still a space to carry out much of work. Many have studied it. Researchers like Johannes Timpe in Alice Walker- Everyday Use (2005), and Natalie Lewis in The Concept of Heritage in Alice Walker's Everyday Use (2001), focus on the concept of black heritage shedding the light on the very metaphor or image of quilting in particular. Also John Gruesser, in Walker's Everyday Use (2003), refers to animal imagery but does not examine the purpose beyond such technique. It just debates over the appropriateness of such imagery to set the rural scene and reinforce these major themes of the story. Those aforementioned studies did not deal with the matter of associating black woman character to animal as a focal point. Its significance as a short story lies in its being a masterpiece which is pregnant of rich secrets. Till now, there is a gap that needs to be abridged. This current study tries to find the aesthetic purpose behind such comparison between black woman and animal.

\section{ALICE WALKER}

Walker is an African American Southern poet, writer, anthologist, and activist. For her humanist principles, she is named in 1997 the" Humanist of the year" by American Humanist Association (Pinn, 2001, p. 288). She was born in 1944, in rural Georgia. She comes from a poor family. Her parents were sharecroppers. She witnessed the hardship of life that African American women had experienced in the American South. She states that her mother was overworked and uneducated woman. She describes her mother's hard " 'working' day, [as] she labored beside- not behind - my father in the field... She made all the clothes we wear... She spent the winter evenings making quilts... Her day began before sunup, and did not end until late at night" (Walker, 1983, p.238). Rather, Walker talks about her mother as an artist. The latter had "fame as a grower of flowers..., people drive by our house in Georgia- perfect strangers and imperfect strangers- and ask to stand or walk among my mother's art"(1983,p.240). Here, her mother's garden is a gallery where aesthetic views are shown.

As an aesthetic theorist, Walker is well- known for her own theory of 'Womanism'. Practically, she applies this theory to her literary works. Her collection of essays, In Search of Our Mothers' Gardens (1983), testifies her perspectives concerning black women's oppression in its varied faces. It particularly sheds the light on experiences of black women. For Walker, like many other African American women writers, the single source of oppression, segregation and dehumanizing is the white race. Regarding this issue, Toni Morrison has stated that "there is no bad luck in the world but white folk" (Beloved, 2004, p. 105). To use Washington's words, Walker is an "apologist for black women- it is clear that the special identity mark of her writing is her concern for the lives of black women"(1979, p.133). In this book, Walker confesses that many of the stories she writes are her mother's. She absorbed not only the stories, but her mother's manner of speaking. These stories are like her life. For this reason, Walker's literary characters have counterparts in real life, which are older than her (Walker, 1983, p. 240). Her fiction is indulged in oral tradition where the stories are in journey from one generation to the next. Her art is for people and by them.

\section{EVERYDAY USE}

Everyday Use is one of the stories included in Walker's collection, In Love and Trouble (1973). It has shone to be the most popular and anthologized among Walker's short stories (Winchell, 1992, p. 80). It is " gynocentric; it is not a story about fathers and sons but about mothers and daughters" (Neo and Jayues, 2009, p.150). It introduces three female characters, (Mum and her two daughters: Dee and Maggie) who are of rural southern roots. Through the narrator, who is the mother Mrs. Johnson, the reader is called to know more about the nature of the characters, the place where they live 
and their way of living. Then, he/she may respond sympathetically. The story is full of description, which works as if it were an aesthetic camera. You feel as if you were witnessing every person, action or scene within the story. The most significant point is that, by means of this description, Walker artfully highlights the connection and closeness between black women and animals. There is a rural environment, and "the story takes place in a 'pasture" " (Gruesser, 2003, p. 183). Such an aesthetic skill of description grants the story a dress of a creative reality. As it is usual in her literary works, Walker tries to flourish the aesthetic, positive, human identity of the black woman and flouts the negative allegations of the white folk.

\section{BLACK WOMAN IMAGE IN THE WHITE EYE}

During slavery age, "comparison of humans to non-humans was often meant to demean the human groups, and this was surely the case with black slaves" in general and black women in particular (Waldau, 2013, p.276). Black women had been exploited by their masters harshly to do domestic as well as agricultural labours. Their double suffering is due to the cruelty and atrocity of the white master and hardness of the black man. In the dictionary of white folk, black females meant animals. They had been dressed animal traits. In other words, black women were considered as "female animals" (Beaulleu, 2006, p.796). They are "the mule[s] of the world, because [they] have been handed the burdens that everyone else- everyone else- refused to carry"(Walker, 1983, p. 237). For their black skin, unmatchable strength and illiteracy, white society adhered animal images to black people in general and black woman in particular. Day claims that the "differences in skin tone, physical features, and language between white and Africans justify the perception of Africans as animals and more a kin to working animals like cows, horses, than other human beings" (1972, p.35). According to the western tradition, black woman cannot reach or emulate the standard of ideal beauty and behaviour that white woman has. In addition to being likened to animals and machines, the black woman is accused of "lacking in reason" because of her closeness to nature more than culture (Nyman, 2003, p.150). Her deprivation of learning, reading and writing is planned. In case she could learn or not, calling her as animal would not be justified at all. Oppressively and aggressively, whites put a social order where black woman has been situated in the last rank. Darlene Clark Hine argues that" stereotypes, negative images, and debilitating assumptions filled the space left empty due to inadequate and erroneous information about the true contributions, capabilities, and identities of Black women"(1994, p.42). In order to show the black woman as a non-human being, all physical and psychological types of tyranny had been practised against her. As a reaction to all such oppressive, cruel and inhuman practices, Walker is committed to turn this negative image upside down. She always puts "African American women's voice at the center of the narrative, unusual position at the time" (Christian, 1994, p.8).

\section{AESTHETIC INVERSION OF NEGATIVE TO POSITIVE}

In the eye of white folk, image of black woman is just like animal or less than animal. She is depicted like mule, cow, horse, dog, or ape, etc. Their claims absolutely are racist. For whites, "race is something only applied to non-white peoples" (Dyer, 1997, p.1). White people reduce blacks to inferior status due to their biological characteristics of black skin, emotion, primitiveness and relatedness to nature. Their distinction between whites as superior (humans) and blacks as inferior (animals) is not only erroneous; rather it is a matter of racial prejudice. Singer thinks that "some blacks are superior to some whites in all of the capacities and abilities that could conceivably be relevant" (1989, p.3). Difference in colour is not acceptable justification for such a racial discrimination. Also concerning the relatedness of blacks to nature and the primitiveness of their culture is not a reason for dehumanizing and devaluing them. Franz Boas defies this claim saying," one should never differentiate high from low culture, and one ought not to differentially valorize cultures as savage or civilized" (cited in Spencer-Oatey, 2012, p.1). No matter whether primitive or civilized, blacks have their own culture which represents their history, heritage, habits, customs and tradition. Edward Burnett Taylor defines culture as " the complex whole which includes knowledge, belief, art, morals, law, custom, and any other capabilities and habits acquired by man as a member of society" (qtd. in Avruch,1998, p.6). Taking for granted Taylor's definition of culture means that black culture is like white culture since it has its own peculiarity which distinguishes it as a unique one. In his Primitive Culture, Taylor argues that culture represents all things which are peculiar to human beings like "hatchet, adze, chisel", and actions like fishing, fire making, wood-chopping, spearing game and shooting (1913, pp.5-6). These tools and recurring activities mentioned by Taylor are used and practiced by African- Americans. No doubt, blacks are humans who have a unique culture.

Goethe argues that "the human being is a central creature among animals; that is, the finished form in which the characteristics of all the various species are assembled in their finest essence" (qtd. in Steiner, 2000). Drawing on Goethe's words, animality state is attributed to all human beings whether they are white or black. As a matter of fact, Goethe sees that "everything appears in the animal must also be present in the human but in [its] higher form" (Steiner, 2006). Both human beings and animals are strongly connected to nature. Such oneness and connection to nature are really the main characteristics that stamp the black culture. In African American language, there are expressions that typically include an attribution of an animal nature or characteristics to people (Widawski, 2015, p. 75).

All the debate above keeps pace with Walker's womanist perspectives towards humans in general and black women in particular. She asserts the relation and connection of humans to animals. Equating human being to animal is not a diminishing or dehumanizing action, but it reflects the high degree of humanity. According to Walker, "[animals] were not made for humans any more than black people [particularly black 
women] were made for whites"(1996, p.14). In her Everyday Use, Walker makes an analogy between black women and animals. Intentionally, she repeats the traits or stereotypes, which white folk pronounce every day to describe black women. White people may think, at first moment, that Walker's expressions are of servile meaning. Actually, Walker tackles such a crucial point in a different way. She mocks at the whites' foolish judgement.

Walker works on inverting the demeaning comparison of black woman to animal into a positive image that makes black woman proud of her identity. Her ridicule of whites' superficiality comes true by proving blacks' ability to play with meaning of words. That also proves the aesthetics and proficiency of black language, which is racially accused of primitiveness.

In Everyday Use, Walker "deal[s] with full characterizations of black women", and she strongly believes that "idealized images of black women need to be protected and reverenced in literature"(Washington, 1975, p. x). She uses the profanity of white language to tell the real story, and the real image of black woman as human and artist as well. The three female characters are associated with animals. For example, Mum's character is associated with cow when she states that: "It seems to me I have talked to them always with one foot raised in flight, with my head turned in whichever way is farthest from them" (Walker,1973, p.49). Also, in another scene both Mum and her daughter Maggie are associated to cow particularly when Dee takes photo for them: 'When a cow comes nibbling around the edge of the yard she snaps it and me and Maggie and the house" (Walker,1973,p.53) The cow moves into the yard then be included in the snapshot. The reader can feel satisfaction and pride of Mrs. Johnson's part when she talks about animals and her relation, closeness and nearness to them. She looks at them as creatures like humans, where they live in the same place. Like Mum, her daughters Maggie and Dee have the same tendency towards the animals. Their acceptance of the appearance of the cow within the photo proves that. As black women, they have intimacy with their animals. Such a tendency is part of their black culture: both humans and animals are related to nature. To define themselves, people in subcultures rely on the significant concepts on which discrimination and separateness by the mainstream culture is based (Kovecses, 2007). Another reference to Mum's connection to cow is that:" Cows are soothing and slow and don't bother you, unless you try to milk them the wrong way" (Walker, 1973, p.51). Mum's words refer to the ethic of caring on the part of black woman. It's about how black woman treats animals and feels equality between humans and animals. In other sense, they all deal with animals as close living creatures. She believes that all creatures are connected to nature. She compares cows to black women, "[b]oth women and animals are sentient creatures... they should not be harmed"(Bourke, 2011, p.94). Those animals are calm and nice, but when they are exposed to harm, their reaction will be violent. On the other hand, Mum's words uncover her knowledge and experience in milking the cows. She artfully practices the job of milking. Black women artfully do their variant jobs, they are genius and artists who leave an aesthetic touch in their work. Concerning associating Maggie's character to animals, Mum says that: "Have you ever seen a lame animal, perhaps a dog run over by some careless person who is ignorant enough to be kind to him"(Walker, 1973, p.49). This description does not regulate Maggie to inferior status, but it refers to oneness of black woman and animal in experience of tyranny. Her suffering is equal to that of a dog. Again Mum describes Maggie's humiliation:" She had filled her bottom lip with checkerberry snuff and it gave her face a kind of dopy hangdog look" (Walker, 1973, p.59). Also, there is reference to Maggie as a fish: "Maggie's hand is as limp as a fish, and probably as cold,..." (Walker, 1973, p.53). Depicting of Maggie as animal is not demeaning at all, but it is a vision of equality between human and animal. Moreover, Dee compares Maggie to an elephant;" Maggie's brain is like an elephant's" (Walker, 1973, p.56). She meant to associate Maggie to an elephant not to a farm animal because it is African animal. That interprets Dees' different strategy in keeping her African identity. She tries to resurrect her African roots. Nevertheless, She does not despise Maggie, but refers to her level of thinking, and how she is patient and satisfied to stay in such a level of poverty. Dee wants to keep her identity by keeping her African roots. She refuses the oppression but in her own way. She refuses her mother and sister's" acquiescence to an oppressive system" (Farrell, 1998, p. 182). Such equality is not defect. Here, I agree with Bourke's "Becoming animal" rhetoric which has been adopted on behalf of African Americans as "a step towards the humanization of [black people] who had been designated lesser humans" (2011, p.93). Such a rhetoric is of a great benefit to black people. It brings shame to the white masters. Here, Maggie is not an animal in the abstract sense of the word; yet she is drawn into passion that one shares with an animal. She has capacities, conditions, in common with this animal. By employing the words aesthetically, Walker focuses on the significant technique of animal epithet which "involve[s] us in richer and more profound relationships with the more- than- human world"(Hooker, 2005, p. 202).

On the other side, Dee, whose character is different to some extent, is also associated to animals. She has been compared to different animals like sheep, lizard, and bird. Mum admired her daughter's character because she is educated, self-centered, determined, and bold. She describes Dee's appearance in a poetic way saying: "It [Dee's hair] stands straight up like the wool on a sheep. It is black as night and around the edges are two long pig-tails that rope about like small lizards disappearing behind her ears"(Walker, 1973.p.52). Poetically, she also describes Dee's voice as: "sweet as a bird" (Walker,1973, p. 56). Since she is a southern black woman, Mum always compares whatever action, appearance or look to animals. She believes that humans and animals are equal in creation. She acquired such belief or habit from her ancestors. Mum's description of her daughter does not express but an admiration of her as an artist. Dee is interested in aesthetics and this proves her 
as a self- creator. She makes her own distinctive style, her hairdo, jewelry or dresses with shining colours. Furthermore, Walker still describes the daughter's "dress down to the ground, in this hot weather. A dress so loud it hurts my eyes... earnings, too, gold and hanging down to her shoulders. Bracelets dangling and making noises when she moves her arm up to shake the folds of the dress out of her armpits..." (Walker,1973, p.52).

Walker does not present her female characters as animals to deny their humanity but to invert the falsified image adhered to them as black women. The evidence is that she presents them, in her own way, as artists. Walker assures her readers that "all [the womanist characters] are artists; Mama, as the narrator, tells her own story; Maggie is the quilt maker, the creator of art..., Dee, the photographer and collector of art, has designed her jewelry, dress and hair... She appears in the story as a self-creation"(Washington, 1994, p. 101-2).

By Alice walker's aesthetic action, it becomes very clear that "the negative connotations of animality can be seen as a construct of alphabetic literacy [white culture], which... tends to diminish the felt connections, common to oral culture, between humanity and the other inhabitants of its natural,[pastoral] environment" (Bloom,2009, p.202). The white folk put the blacks in inferior status and attribute to them the traits of that illiteracy and primitiveness. Literacy is not "qualified signifier of cultural superiority". Walker clarifies her eco- perspective in her essay Am I Blue, saying that: " what animals try to tell us is this: "Everything you do to us will happen to you; we are your teachers, as you ours. We are one lesson"(Bloom, 2009, p. 202).

\section{TROPE OF SIGNIFYING}

Here, I try to prove that Walker's aesthetic action of how comparing black womanist image to that of animal is an action of signifying. By and large, signifying is an African American literary tradition. Its use is attributed to Africans. According to Michael Cook, it "constitutes one of the hall marks of African- American creativity and verbal expression" (cited in Hawkin-Dady, 2012, p. 12). There are different perspectives of the concept of signifying. The critic Roger Abrahams, for instance, states that to signify is "to imply, goad, beg, boast by indirect verbal or gestural means. A language of implication" (2006, p.267). The technique of signifying could express a double meaning. One matches the black interpretation, and the other matches the white interpretation. Signifying is a "black double voicedness" and "it depends on the homonymic relation of the white term to the black", to use the words of Gates (1989, p. 50, 51). It is "direction through indirection" (Abrahams, 2006, p.70). In applying the perspective of signifying to Walker's expressions that compare black female to animals, I find that she has an intention beyond that. She uses the same expressions that are common among the white folk. She pays back their expressions to them but with the opposite meaning. According to Hurston "language is like money" (1934, qtd. in Wall, 2005, p.4). The surface meaning is quite different from the intended meaning. Bakhtin thinks that " a double-voiced word or [expression is similar to] a special sort of palimpsest in which the upper-most inscription is a commentary on the one beneath it, which the reader... can know only by reading through the commentary that obscures in the very process of evaluation" (qtd. in Gates, 1989, p.50). Here, the black interpretation is the contrary to the white one. The white interpretation tends to attribute whatever animal trait to the black women. It denies whatever human trait those women have. It steals their right of humanity. On the contrary, the black interpretation tries to encounter the negative view towards black women. Walker creates new aesthetic meaning from profanity of whites. She works on polishing the black woman image. According to her, the black woman is a human being and artist as well. Black woman has an artistic touch whether in domestic or creative works like sewing, quilting, gardening, storytelling, and even husbandry. This woman has humanity and creativity. She is a human being who believes in coexistence with other creatures like animals. Moreover, she feels equality, closeness and connection to animals. The reader feels this connection in the story: "This house is in a pasture"(Walker, 1973, p.51). This refers to the coexistence of black females with animals, which Walker asserts saying that she feels an amazing connection with animals and she is aware that she is truly coexisting with them (Bring, 1988, p73.). In the story, Mum is happy and proud of closeness to animals since they live in one house. Another thing is that Mrs. Johnson is a simple woman but an artist in narration, quilting and even taking care of animals. She talks about the good way to milk the cows: "Cows are soothing and slow and don't bother you, unless you try to milk them the wrong way"(Walker, 1973 , p.51). Also the reader can feel how Walker focuses on equality between animals and the black women since both of them "are one lesson" (Bloom, 2009, p. 202). Both are slaves and white people exert tyranny over them. Black people who experienced slavery can feel the total dominance of human beings (whites) over animals, then they compare themselves to labor animals like mules and horses. Blacks "look to the barnyard...to find other living creatures in their plantation world whose subjugating resembled their own" (Bay, 2000, 135). Walker brings a transformation, which is that association of the black woman negatively to animals has changed into positive identity.

On the other hand, in her journey of looking for her biological or literary mothers' gardens, Walker imparts their impact on her "love of beauty", art, and "respect for strength"(Walker,1983,p.241). Literarily speaking, Zora Neal Hurston as a prior writer has an impact on Walker as a successor African American writer. Walker declares that Zora "had already done a thorough job of preparing the ground over which I was then moving"(1983, p.13). Zora is Walker's literary model. She is her "authority figure" (Gates,1989, p.244). Now I can say that Walker is signifying on Zora Neal Hurston, especially in employing the animal image. According to Gates' The Signifying Monkey: A Theory of African-American Literary Criticism (1989), signifyin(g) "always entails formal revision and intertextuality relation... it [is] an ideal metaphor for black liter- 
ary criticism, for the formal manner in which texts seem concerned to address their antecedents. Repetition, with a signal difference, is fundamental to the nature of signifyin $(\mathrm{g})$ " (p.51). Gates maintains that "[B]lack writers... read, repeated, imitated, and revised each other's texts to a remarkable extent"(1989, p. xxii). In her aesthetic action of comparing black women to animals, Walker focuses on the same key point of signifying. With a different type of treatment, she has repeated what had been discussed in her precedent Zora Neal Hurston's Mules and Men (1935). In her significant work, Zora presents a coded message about the nature of black people. She "transformed black people's identification with the mule-an overworked beast of burden" into positive image (Hemenway,1980, p.222). To Hurston, the matter is that of a double meaning expression: the direct meaning relates southern black people to animals of burden. This meaning is acceptable enough by white people. The other meaning is implicit. More clearly, Hurston argues that black people are like mules because both of them "were forced to work long hours" and "they were defiantly human-mules". Hurston inverts the negative relation of black people to mules "(slave: mule: beast of burden) into positive identity (beast of burden: mule: slave: man)" (Hemenway, 1980, p. 222). This action by Hurston is also an aesthetic one as she artfully shows "the intrinsic beauty of [her] folk expression" (Hemenway, 1980, p.222). She is signifying on the white expression, which is direct. Implicitly her expression "Mules and Men" shows the similarity between black people and the mules but in an intended positive way. Both had been captivated and enslaved by white people and exploited to do field labour. Those black people benefited from being depicted as mules. In other words, relating them to mules represents their strength, patience and productivity.

One can conclude that both Walker and Hurston are signifying on the expressions of white folk. The two writers show the disability of white language in comparison to that of blacks. In her Characteristics of Negro Expression (1934), Hurston states that "black Americans are barterers, whose words embody their meaning. By contrast, white Americans... use language like checks; their words stand a purely abstract relation to their meaning" (qtd. in Wall, 2005, p.4). On the other hand, Walker is signifying on her literary model Hurston. She also inverts the negative, racist image that relates black women to animals into an aesthetic human identity.

\section{MUCH THE SAME: AESTHETIC INVERSION AND AESTHETIC QUILTING}

The work of African American women writers can also be said to form a patchwork quilt. The literary patchwork quilt of these remarkable women had been growing since Phyllis Wheatley laid the first piece down, and since then, the different novelists, poets, and dramatists have been contributing their pieces from a rainbow spectrum of colours and textures. (Jia, 1999, p.2)

Depending on the quotation above, I can say that Walker's aesthetic inversion of a negative image about black women into a positive one is parallel to the aesthetic action of quilting by her maternal ancestors. She shares her grandmothers' aesthetic action. It can be considered as a fictional quilting. Reveira argues that the" shared etymological origins between words such as text and textile or fabric and fabrication seem to indicate that the construction of elements made with cloth is relatively similar to the creation of word-based stories" (2006,p.11). Like the creative maternal ancestors who converted ragged bits of clothes into aesthetic work by using the needle, Walker inverts the negative, false, debilitating portrayal to aesthetic one via the pen. The old pieces of everyday used clothes, which belong to the ancestors, and the animal images, which are everyday used and attributed to black women, both share the "Everyday Use" quality. There is parallelism between "the creation... of quilts' and 'the construction of a written text" (Jia,1999, p.17). The skills or qualities like attention, patience, perseverance, and confidence, which black females have, are required for writing and needlework like embroidery, sewing, and quilting (Douglas, 2017, p.65). For Walker, artist can leave her print in the materials she produces, and through the medium she is allowed to use in her society (1983, p.239). In her important study, the Needle or the Pen: The Literary Rediscovery of Women's Textile Work, Hedges argues that "the pen was really only a needle"(1991, p. 341). Here, Hedges gives priority to the needle rather than the pen. No matter how Walker (the writer) and her grandmothers (the quilters) do this creative aesthetic job. The important matter is that letting the fact shine: black women are genius artists not just female animals to be exploited in field or domestic labour. They artfully prove the very contrary picture. Both aesthetic actions, quilting and writing, are to mirror black women's self- identity, cultural identity, and connection to black heritage and history.

\section{CONCLUSION}

On the part of Alice Walker, comparing black woman to animal is not to steal her human identity; on the contrary, it is an aesthetic action toward rooting the black woman's character. It is not shortcoming but virtue. Walker is against disfeaturing aesthetics of black woman identity. To accomplish her job, she follows certain aesthetic techniques. Those techniques are rooted in African American history, culture and heritage. Walker's action is artfully and thematically constructed on the key elements of inversion, signifying, and quilting-like. Inverting such a false negative image about black woman into one that smells of art spirit is to ridicule the superficiality of white language and culture. Walker succeeds in proving humanity and creativity of her female characters. At the same time, she proves that such humanity and creativity represent the root of black culture. So the black woman appears again as a human being who believes in oneness of creatures, a hard worker who has unlimited patience and resistance, and an artist who does her different jobs aesthetically. Through her literary work, Walker is aesthetically quilting a nice image of African American women. This image identifies 
and celebrates black women as humanist, responsible, strong, able, independent, resistant and resilient beings. Consequently, she makes all the fallacious white masks fall down.

\section{REFERENCES}

Abraham, R. D. (2006). Deep down in the jungle: black American folklore from the street of Philadelphia. USA: Transaction.

Avruch, K. (1998). Culture and conflict resolution. Washington DC: Institute of Peace Press.

Bay, M. (2000). The white image in the black mind: African-American ideas about white people. New York: Oxford University Press.

Beaulleu, A. E. (Ed.). (2006). Writing African American women: $K-Z$. USA: Green Wood Publishing Group.

Bloom, H. (Ed.). (2008). The color purple. New edition. New York: Info base publishing.

Bloom, H. (Ed.). (2009). Alice Walker. New York: Info base Publishing.

Bourke, J. (2011). What it means to be human: Reflections from 1791 to the present. London: Virago.

Bring, E. (1988). Moving towards coexistence: Interview with Alice Walker. In Alice Walker (2010). The world has changed: Conversations with Alice Walker. New York: New Press.

Castro-Borrego, S. (2011). The search for wholeness and diaspora literary in contemporary African American literature. New York: Cambridge Scholar Publishing.

Christian, B. (Ed.). (1994). Women writers: Texts and contexts, Everyday use: Alice Walker. New Brunswick, New Jersey: Rutgers University Press

Collins, h. P. (1996). What 's in a name? Womanism, black feminism, and beyond. Black Scholar, 26 (1), 9-17.

Day, B. (1972). Sexual life between blacks and whites: The roots of racism. Michigan: American Sociological Association.

Douglas, A. (2017). Work in hand: Script, print, and writing, 1690-1840. UK: Oxford University Press.

Dyor, R. (1997). White. London: Routledge.

Farrell, S. (1998). Fight vs. flight: A re-evaluation of Dee in Alice Walker's “Everyday Use". In Studies in Short Fiction, 35, 179-186.

Gates, H. L. (1989). The signifying monkey: A theory of African American literary criticism. USA: Oxford University press.

Gruesser. J. (2003). Walker's everyday use. The Explicator, 61(3), 183-185.

Hawkin-Dady, M. (2012). Reader's guide to literature in English. USA: Routledge.

Hedges, E. (1991). The needle or the pen: The literary rediscovery of women's textile work. In Florence Howe (Ed.), Traditions and the talents of women (pp. 339363). Urbana: University of Illinois Press.

Hemenway, R. E. (1980). Zora Neale Hurston: A literary biography. USA: University of Illinois Press.
Hine, D. C. (1994). Hine sight: Black women and the re-construction of American history. Carlson Publishing.

Hooker, D. A. (2005) Reanimating the trope of talking book in Alice Walker's strong horse tea. In Harold Bloom (Ed.) (2009), Alice Walker. (pp.187-207). New York: Info base Publishing.

Jia, L. L. (1999). Gloria Naylor's colours in the patchwork quilt of African American fiction, (Master Thesis, Durham University). Retrieved from http://etheses.dur. ac.uk/4400/.

Kovecses, Z. (2007). Studying American culture through its metaphors: Dimensions of variation and frames of experience. American E. Journal of American Studies in Hungary, III (10).

Lauret, M. (20011). Alice Walker. Palgrave Macmillan.

Lewis, N. (92001). The concept of heritage in Alice Walker's everyday use. Retrieved from http://www.grin.com/ en/e-book/5434/the-concept-of-heritage-in-alice-walker-s-everyday use.

Morrison, T. (2004). Beloved. New York: Random House Inc.

Neo, M. and Jayues, M. (2009). Teaching Alice Walker's Everyday use: Employing race, class, and gender, with an annotated bibliography. In Harold Bloom (Ed.), Alice Walker. New York: Info base Publishing.

Nyman, J. (2003). Postcolonial animal tale from Kipling to Coetzee. New Delhi: Atlantic Publishers \& Distributors.

Phillips, L. (Ed.) (2006). The womanist reader. New York: Taylor \& Francis Group.

Pinn, B. A. (2001). By these hands: A documentary history of African American humanism. New York \& London: New York University Press.

Reveira, E. M. (2006). The quilt as text: Reading women's culture in American short stories (1845-1988), (Dissertation, University of Santiago).

Singer, P. (1989). All animals are equal. Retrieved from http://rintintin.colorado.edu/ vancecd/phil 3140/singer1. Pdf.

Smith, K. K. (2012). Governing animals: Animal welfare and the liberal state. New York: Oxford University Press.

Spencer-Oatey, H. (2012). What is culture? A compilation of quotations. Retrieved from http: go-e warwick.ac.uk/ globalpadintercultur.

Steiner, R. (2000). The origin of Goethe's thinking on animal morphology: Works 2 of 16 (John Barnes \& Mado Spiegler Trans.). USA: Anthroposophic Press. Retrieved from http://books google.iq./books / $\mathrm{id}=$ mneeCnctw-iC\&pg=PT1\&dq.

Steiner, R. (2006). Autobiography: Chapters in the course of my life; 1861-1907 (Rita Stebbing Tran.). Great Barring: Anthroposophic.

Taylor, E. B. (1913). Primitive culture. (5 $5^{\text {th }}$ ed.) London.

Timpe, J. (2005). Alice Walker: everyday use. Retrieved from http:/www.grin.com/en/e-book/109406 Alice-walker-everydayuse Waldau, P. 92013). Animal studies: An introduction. New York: Oxford University Press. 
Walker, A. (1973). In love and trouble. New York: Harcourt Brace.

Walker, A. (1983). In search of our mothers' Gardens: Women prose. New York: Harcourt Brace Jovanovich.

Walker, A. (1996). Foreword. In Spiegel, M. The dreaded comparison- human and slavery: Mirror books/1.D.E.A., New York, p.14.

Wall, C. A. (2005). Jump in at the sun: Reassessing the life and work of Zora Neale Hurston. The Scholar \& Feminist Online. 3(2), 1-6.
Washington, M. H. (1975). Black-eyed Susans: Classic stories and about black women. New York: Garden City, Doubleday.

Washington, M. H. (1979). An essay on Alice Walker. In Roseenn P. Bell et al. Study black bridge: Vision of black women in literature. Garden City, New York: Anchor Press/Doubleday.

Washington, M. H. (1994). An essay on Alice Walker. In Barbara Christian. Everday use: Alice Walker.New Brunswick. New Jersey: Rutgers University Press.

Winchell, D. H. (1992). Alice Walker. New York: Twayne. 